\title{
Comparison of the separation of large DNA fragments in the presence and absence of electroosmotic flow at high $\mathrm{pH}$
}

\author{
Tai-Chia Chiu, Huan-Tsung Chang* \\ Department of Chemistry, National Taiwan University, Section 4, Roosevelt Road, Taipei, Taiwan
}

\begin{abstract}
This paper describes the analysis of large DNA fragments at $\mathrm{pH}>10.0$ by capillary electrophoresis (CE) in the presence of electroosmotic flow (EOF) using hydroxyethylcellulose (HEC) solution. HEC solution in the anodic reservoir enters the capillaries filled with high-pH buffer by EOF after sample injection. With respect to resolution, sensitivity, and speed, separation conducted under discontinuous conditions (different $\mathrm{pH}$ values of HEC solutions and buffer filling the capillary) is appropriate. Using HEC solution at concentrations higher than its entanglement threshold ensures a good separation of large DNA fragments in the presence of EOF at high $\mathrm{pH}$. In addition to $\mathrm{pH}$ and HEC, the electrolyte species, dimethylamine, methylamine, and piperidine, play different roles in determining the resolution. The separation of DNA fragments ranging in size from 5 to 40 kilo base pairs was completed in 6 min using 1.5\% HEC prepared in $20 \mathrm{mM}$ methylamine-borate, $\mathrm{pH} 12.0$, and the capillary filled with $40 \mathrm{~m} M$ dimethylamine-borate, $\mathrm{pH}$ 10.0. In comparison, this method allows faster separations of large DNA fragments compared with that conducted in the absence of EOF using dilute HEC solutions.
\end{abstract}

(C) 2002 Elsevier Science B.V. All rights reserved.

Keywords: Electroosmotic flow; Buffer composition; DNA

\section{Introduction}

Capillary electrophoresis (CE) using polymer solutions has become a major technique for DNA sequencing and the analysis of polymerase chain reaction (PCR) products [1-3]. It has considerably assisted the rapid progress in the Human Genome Project, and has driven the success of completing the draft sequence well ahead of schedule [4,5]. The success of $\mathrm{CE}$ in this regard is due in part to the use of replaceable polymer solutions with a high sieving ability. A number of hydrophilic polymers, such as linear polyacrylamide (LPA) and its derivatives [6-

\footnotetext{
*Corresponding author. Tel.: + 886-2-2362-1963; fax: + 886-22362-1963.

E-mail address: changht@ccms.ntu.edu.tw (H.-T. Chang).
}

9], cellulose and its derivatives [10-12], polyvinylpyrrolidone (PVP) [13], and poly(ethylene oxide) (PEO) [14], have been tested successfully. Commonly, deactivated capillaries are used to minimize the variation in electroosmotic flow (EOF) and DNA adsorption on the capillary wall $[15,16]$.

The analysis of large DNA fragments is of considerable interest and importance in many respects. It helps to assess the effect of tumorigenesis on telomeres by measurement of variations in telomeric length (7-10 kilo base tandem repeats of 5'TTAGGG-3' in humans) that exists between individuals, between chromosomes and between cells within an individual [17]. However, the analysis of small variations in large DNA fragments is not easy. It is known that the electrophoretic mobility of long DNA fragments becomes independent of the molecu- 
lar size and DNA fails to enter the gel or is trapped by the sieving matrix [18]. To achieve a reasonable resolution, a number of polymer solutions at concentrations below their entanglement threshold $\left(\Phi^{*}\right)$ have been employed for the separation of kilo base pair (kbp) DNA [19-21]. The success of these separations stems from the fact that DNA drags along the polymer molecules it encounters during migration, with support from the dynamic formation and deformation of the U-shaped DNA conformation $[18,22]$. In addition, it has been suggested that the relative DNA/HEC size plays a significant role in determining the resolution and no a priori upper size limit to DNA by CE in a constant field is anticipated [19-23]. Alternatively, pulsed-field capillary gel electrophoresis (PFCGE) is employed for the analysis of DNA fragments up to $1.6 \mathrm{Mbp}$, with a faster analysis compared with pulsed-field gel electrophoresis [19]. However, this system is relatively complicated.

Alternatively, we have demonstrated the separation of kbp DNA at $\mathrm{pH} 8.2$ in the presence of $\mathrm{EOF}$ using PEO solution with concentrations above its $\Phi^{*}$ [24]. However, the fact that the EOF decreases gradually due to the dynamic coating of PEO molecules on the capillary wall needs to be carefully considered in terms of speed and reproducibility $[25,26]$. We have concluded that adsorption is more profound using high concentrations of PEO solution when the capillary is filled with low concentrations of Tris-borate (TB) buffer. Although we have also found that PEO adsorption is less at high $\mathrm{pH}$, the analysis of DNA using PEO is not quite successful because of the hydrolysis of PEO. On the other hand, we also realize that the analysis of DNA at high $\mathrm{pH}$ might be faster, due to less PEO adsorption, and more sensitive, because of the stronger fluorescence of DNA intercalated with ethidium bromide (EtBr). Thus, the development of a method for the separation of large DNA fragments at high $\mathrm{pH}$ is worthy from a practical point of view. In this study, we tested the separation of large DNA fragments at $\mathrm{pH}$ values ranging from 8.0 to 12.0 using HEC solution in the presence of EOF. We explored the effect of buffers prepared from borate and three different amines on DNA separation. Unlike at $\mathrm{pH}$ 8.2, HEC solutions at concentrations much greater than the $\Phi^{*}$ had to be used for the separation of large DNA fragments at $\mathrm{pH}>10.0$.

\section{Materials and methods}

\subsection{Equipment}

The basic design of the separation system has been described previously [24]. Briefly, a high-voltage power supply (Gamma High Voltage Research, Ormond Beach, FL, USA) was used to drive electrophoresis. The entire detection system was enclosed in a black box with a high-voltage interlock. The high-voltage end of the separation system was placed in a laboratory-made Plexiglass box for safety. A 1.5-mW $\mathrm{He}-\mathrm{Ne}$ laser with $543.6 \mathrm{~nm}$ output from Uniphase (Mantence, CA, USA) was used for excitation. The light was collected with a $10 \times$ objective (numerical aperture 0.25). A RG 610 cutoff filter was used to block scattered light before the emitted light reached the photomultiplier tube (Hamamatsu R928). The amplified currents were transferred directly through a $10 \mathrm{k} \Omega$ resistor to a 24-bit A/D interface at $10 \mathrm{~Hz}$ (Borwin, JMBS Developments, Le Fontanil, France) and stored in a personal computer. Bare fused-silica capillaries (Polymicro Technologies, Phoenix, AZ, USA) with $75 \mu \mathrm{m}$ I.D. and $365 \mu \mathrm{m}$ O.D. were used.

\subsection{Chemicals}

All chemicals for preparing buffer solutions and polymers were from Aldrich (Milwaukee, WI, USA). $\mathrm{EtBr}$ was obtained from Molecular Probes (Eugene, OR, USA). Solutions prepared from methylamine, dimethylamine, and piperidine were adjusted with suitable amounts of boric acid to $\mathrm{pH}$ values ranging from 8.0 to 12.0 and thus the prepared solutions are called MB, DB, and PB buffers, respectively. Unless otherwise noted, $\mathrm{X} \mathrm{m} M \mathrm{MB}$, DB or PB buffer indicates an $\mathrm{X} \mathrm{m} M$ amine solution adjusted with a suitable amount of boric acid. These buffers were used to fill the capillaries when the separations were carried out in the presence of EOF. Certain amounts of HEC (molecular mass $1300000 \mathrm{~g} / \mathrm{mol}$ ) were added separately to $50 \mathrm{~mL}$ of $20 \mathrm{~m} M \mathrm{MB}$, DB, and $\mathrm{PB}$ containing $5 \mu \mathrm{g} / \mathrm{ml} \mathrm{EtBr}$, and the prepared HEC solutions were used for DNA separations. For the experiments conducted in the absence of EOF, HEC solutions were also prepared in $1 \times \mathrm{TBE}, \mathrm{pH} 8.2$. ФX 174 RF DNA-HaeIII digest and KiloBase DNA marker were purchased from Pharmacia Biotech 
(Uppsala, Sweden) and were used only when the separations were carried out in the presence of EOF. A $5 \mathrm{~kb}$ DNA ladder was purchased from Gibco/BRL (Bethesda, MD, USA).

\subsection{Separation in the presence of EOF}

Prior to analysis, capillaries were treated with 0.5 $M \mathrm{NaOH}$ overnight [25]. After each run, capillaries were washed with $0.5 M \mathrm{NaOH}$ at $1 \mathrm{kV}$ for 10 min to remove HEC solutions and to refresh the capillary wall, and subsequently filled with $\mathrm{MB}, \mathrm{DB}$ or $\mathrm{PB}$ buffer. This treatment was quite successful with respect to speed and reproducibility. The bulk EOF mobilities were greater than $5.8 \cdot 10^{-4} \mathrm{~cm}^{2} \mathrm{~V}^{-1} \mathrm{~s}^{-1}$, with relative standard deviation (RSD) values $<2.0 \%$. The injection of DNA samples was carried out by electrokinetic injection at $1 \mathrm{kV}$ for $10 \mathrm{~s}$. During the analysis, HEC solutions in the anodic reservoir entered the capillary by EOF and served as sieving matrices for DNA separations. Owing to the bulk EOF mobilities being greater than the electrophoretic mobility of DNA migrating against the EOF, large DNA fragments were detected earlier towards the cathode end.

\subsection{Separation in the absence of EOF}

For the separation of the $5 \mathrm{~kb}$ DNA ladder in the absence of EOF, 5\% PVP was used to dynamically coat the capillary overnight. Prior to separation, the capillary was washed with TB buffer and subsequently filled with $0.05 \%$ HEC solutions at different $\mathrm{pH}$ values. In the absence of EOF, DNA migrated towards the anode when a negative electric field of $25 \mathrm{~V} / \mathrm{cm}$ was applied. After each run, the capillary was coated with PVP to achieve optimum resolution and reproducibility.

\section{Results and discussion}

\subsection{Impact of amines and $\mathrm{pH}$}

Although $\mathrm{pH}$ affects the electrophoretic mobility of DNA, intercalation, the quantum yield of intercalated DNA, and the stability of the capillary coating, only a few reports deal with its impact on DNA separation in CE [26-28]. Magnusdottir et al. found improvements in resolution for the separation of DNA fragments at neutral $\mathrm{pH}$ using histidine buffers [29]. Boček's and Kuhr's groups individually demonstrated that the separation efficiency is much greater at high $\mathrm{pH}(>10.0)[7,30,31]$. Tseng and Chang have recently developed a technique based on a $\mathrm{pH}$ junction for optimizing the sensitivity and resolution of the analysis of DNA [32]. In the present study, we further evaluated the effect of $\mathrm{pH}$ in the range 10.0 to 12.0 on the separation of DNA using PB, DB, and MB buffers. Table 1 shows that, in the presence of EOF (counter flow), the analyses conducted either at $\mathrm{pH} 10.0$ or 11.0 were more successful in terms of sensitivity, and the results are in good agreement with the maximum quantum yields of intercalated DNA at about $\mathrm{pH} 11.0$ [33]. Using these conditions, the separations were faster $(<13 \mathrm{~min})$ due to high EOF mobilities $\left(>5.8 \cdot 10^{-4}\right.$ $\mathrm{cm}^{2} \mathrm{~V}^{-1} \mathrm{~s}^{-1}$ ). At high $\mathrm{pH}$, peak profiles (peak width for the 1353-bp fragment $<0.02 \mathrm{~min}$ at half-height) for the DNA fragments were sharp, mainly due to weaker interactions with the capillary wall. On the other hand, the separation was not suitable at $\mathrm{pH}$ 12.0, mainly because of Joule heating, weak intercalation between $\mathrm{EtBr}$ and the DNA fragments, and partial denaturation of DNA $[33,34]$. In addition, the relatively small bulk EOF $\left(<3.5 \cdot 10^{-4} \mathrm{~cm}^{2} \mathrm{~V}^{-1}\right.$ $\mathrm{s}^{-1}$ ) compared with that at $\mathrm{pH} 9.0-11.0$ is problematic for the separation of small DNA fragments. It took more than 17 min for the small DNA fragments $(<72 \mathrm{bp})$ that have higher electrophoretic mobilities, and thus resolution was lost due to peak broadening [8]. Despite the $\mathrm{pH}$ effect, Table 1 also shows that the amines affected the sensitivity and resolution of the separation of the $\Phi \mathrm{X} 174$ RF DNA-HaeIII digest. As suggested by several groups [35,36], such effects may be due to changes in DNA conformation (hydrogen bonding) and the interaction between DNA and EtBr.

It is also interesting to note that the EOF mobilities are different at the same $\mathrm{pH}$ when using different amines to prepare the buffers. For example, using $1.7 \%$ HEC prepared in $20 \mathrm{~m} M$ DB buffer, $\mathrm{pH}$ 11.0, the EOF mobilities were 7.28, 5.98, and 6.83. $10^{-4} \mathrm{~cm}^{2} \mathrm{~V}^{-1} \mathrm{~s}^{-1}$ when the capillary was filled with $40 \mathrm{~m} M \mathrm{~PB}, \mathrm{MB}$, and DB buffers, $\mathrm{pH} 11.0$, respectively. Owing to slight differences in the conductivity $(<20 \mu \mathrm{A})$, the viscosity change due to Joule heating should be neglected. In the presence of HEC, 
Table 1

Effect of $\mathrm{pH}$ and background electrolyte on the separation of $\Phi \mathrm{X} 174 \mathrm{RF}$ DNA-HaeIII digest in the presence of $\mathrm{EOF}^{\mathrm{a}}$

\begin{tabular}{|c|c|c|c|c|c|c|c|c|c|c|c|c|c|c|c|c|c|c|c|c|c|c|c|c|c|}
\hline \multirow{3}{*}{\multicolumn{2}{|c|}{$\begin{array}{l}\text { Buffer } \\
(40 \mathrm{~m} M) \\
\text { filling the } \\
\text { capillary }\end{array}$}} & \multicolumn{8}{|c|}{ Peak height $^{\mathrm{b}}(\mathrm{V})$} & \multicolumn{8}{|c|}{ Bandwidth $^{\mathrm{b}}\left(\mathrm{w}_{1 / 2}, \mathrm{~min}\right)$} & \multicolumn{8}{|c|}{ Resolution (1353/1078) } \\
\hline & & \multicolumn{3}{|c|}{ pH 10.0} & \multicolumn{3}{|c|}{$\mathrm{pH} 11.0$} & \multicolumn{2}{|c|}{ pH 12.0} & \multicolumn{3}{|c|}{$\mathrm{pH} 10.0$} & \multicolumn{3}{|c|}{ pH 11.0} & \multicolumn{2}{|c|}{$\mathrm{pH} 12.0$} & \multicolumn{3}{|c|}{$\mathrm{pH} 10.0$} & \multicolumn{3}{|c|}{ pH 11.0} & \multicolumn{2}{|c|}{ pH 12.0} \\
\hline & & PB & MB & $\mathrm{DB}$ & $\mathrm{PB}$ & $\mathrm{MB}$ & $\mathrm{DB}$ & $\mathrm{PB}$ & MB & РB & $\mathrm{MB}$ & DB & PB & MB & DB & $\mathrm{PB}$ & MB & $\mathrm{PB}$ & MB & DB & $\mathrm{PB}$ & MB & $\mathrm{DB}$ & $\mathrm{PB}$ & MB \\
\hline 10.0 & \multirow[t]{3}{*}{ PB } & 0.33 & 0.82 & 0.05 & 0.38 & N.D. & 0.18 & N.D. & N.D. & 0.02 & 0.01 & 0.01 & 0.02 & N.D. & 0.03 & N.D. & N.D. & 2.48 & 2.72 & 2.02 & 3.24 & N.D. & 1.13 & N.D. & N.D. \\
\hline 11.0 & & 0.62 & 0.42 & 0.11 & 0.58 & 0.11 & 0.37 & N.D. & N.D. & 0.03 & 0.01 & 0.02 & 0.03 & 0.02 & 0.02 & N.D. & N.D. & 2.31 & 2.69 & 0.62 & 2.90 & 1.38 & 1.40 & N.D. & N.D. \\
\hline 12.0 & & N.D. ${ }^{c}$ & 0.67 & 0.05 & 0.17 & 0.03 & 0.87 & 0.45 & 0.42 & N.D. & 0.02 & 0.02 & 0.03 & 0.03 & 0.02 & 0.03 & 0.02 & N.D. & 2.36 & 0.23 & 1.02 & 1.49 & 1.38 & 0.62 & 1.92 \\
\hline 11.0 & \multirow{2}{*}{ MB } & 0.34 & 1.59 & 0.24 & 0.38 & N.D. & 1.89 & 1.00 & N.D. & 0.02 & 0.01 & 0.02 & 0.05 & N.D. & 0.02 & 0.02 & N.D. & 2.26 & 2.73 & 1.94 & 1.12 & N.D. & 2.06 & 1.52 & N.D. \\
\hline 12.0 & & 0.72 & 0.84 & 0.10 & 0.42 & 0.41 & 0.70 & 1.18 & N.D. & 0.04 & 0.03 & 0.02 & 0.03 & 0.02 & 0.03 & 0.03 & N.D. & 0.78 & 1.45 & 1.77 & 2.18 & 1.61 & 1.77 & 0.59 & N.D. \\
\hline 10.0 & \multirow[t]{3}{*}{ DB } & 1.74 & 1.23 & 0.26 & 0.29 & N.D. & 1.02 & N.D. & N.D. & 0.01 & 0.01 & 0.02 & 0.02 & N.D. & 0.02 & N.D. & N.D. & 1.35 & 2.80 & 2.66 & 2.66 & N.D. & 1.54 & N.D. & N.D. \\
\hline 11.0 & & 1.61 & 1.78 & 1.04 & 0.43 & N.D. & 1.42 & N.D. & N.D. & 0.01 & 0.01 & 0.01 & 0.02 & N.D. & 0.02 & N.D. & N.D. & 2.38 & 2.90 & 2.16 & 2.18 & N.D. & 2.24 & N.D. & N.D. \\
\hline 12.0 & & 1.41 & 0.76 & 0.48 & 0.12 & 1.35 & 1.65 & 1.40 & N.D. & 0.03 & 0.02 & 0.02 & 0.04 & 0.02 & 0.02 & 0.02 & N.D. & 1.13 & 2.36 & 2.06 & 0.80 & 1.89 & 2.07 & 1.97 & N.D. \\
\hline
\end{tabular}


the magnitude of the EOF does not simply relate to ionic strength and the extent of dissociation of $\mathrm{SiOH}$ on the capillary wall, because the species adsorbed on the capillary wall not only directly affect the EOF, but also affect the EOF by changing the extent of HEC adsorption $[25,26]$. In these studies, we also showed that HEC adsorption decreases with increasing ionic strength and $\mathrm{pH}$, and is less on a hydrophilic wall. It is known that DNA interactions with the capillary wall decrease, and thus reproducibility and resolution improve, when using a capillary coated with HEC [21]. Thus the buffer species also affects the peak profiles and resolution, as shown in Table 1. Overall, we suggest that, on the basis of sensitivity, two conditions are more appropriate: (1) the capillary is filled with $40 \mathrm{~m} M \mathrm{DB}, \mathrm{pH} 11.0$, when using $1.7 \%$ HEC prepared in $20 \mathrm{mM} \mathrm{MB}$, pH 10.0; and (2) the capillary is filled with $40 \mathrm{mM} \mathrm{MB}$, $\mathrm{pH} 11.0$, when using $1.7 \%$ HEC prepared in $20 \mathrm{mM}$ $\mathrm{DB}, \mathrm{pH}$ 11.0. Regarding the resolution, the former is superior for the separation of large DNA fragments.

\subsection{Effect of HEC}

Unlike for the separation of small DNA fragments, $40 \mathrm{~m} M$ DB buffer, $\mathrm{pH} 12.0$, and $20 \mathrm{~m} M$ MB buffer, $\mathrm{pH} 10.0$, were used to fill the capillary and prepare the HEC solution, respectively, for the separation of the kbp DNA marker. Using these conditions, a greater resolving power was achieved, mainly because DNA migrated against a smaller EOF mobility $\left(3.5 \cdot 10^{-4} \mathrm{~cm}^{2} \mathrm{~V}^{-1} \mathrm{~s}^{-1}\right)$, leading to a longer separation time. Fig. 1 shows the striking result that the large DNA fragments were only separated at higher HEC concentrations at high $\mathrm{pH}$, which is in contrast to the results obtained by others [20] and to our previous result using $\mathrm{PEO}$ at $\mathrm{pH} 8.0$ [24]. With increasing HEC concentration, both the EOF and the diffusion coefficient of DNA decreased. As a result, the selectivity (longer residence times) and efficiency improved, leading to better resolution. Our reasoning is supported by the fact that an electropherogram showing 10 peaks was only achieved using $2.0 \%$

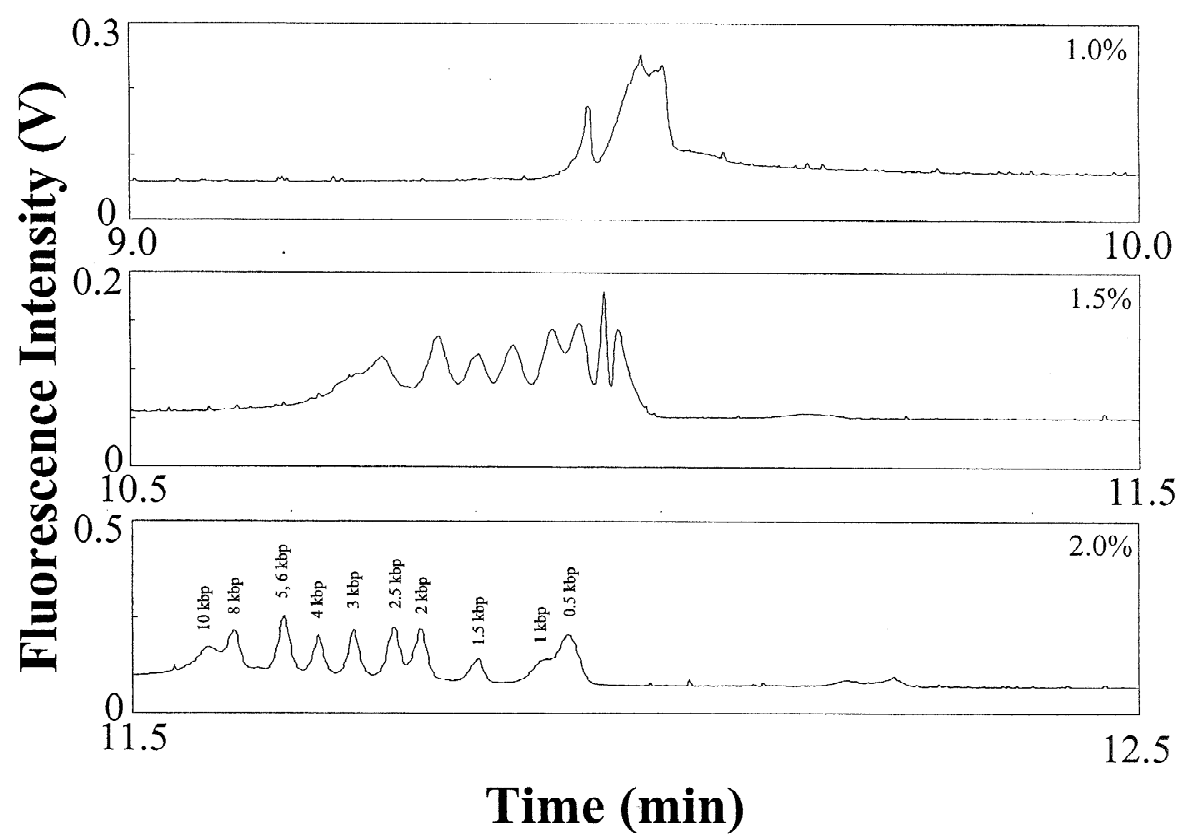

Fig. 1. Separation of a $25 \mu \mathrm{g} / \mathrm{mL}$ kbp DNA marker in the presence of EOF at $250 \mathrm{~V} / \mathrm{cm}$ using different HEC solutions containing $5 \mu \mathrm{g} / \mathrm{mL}$ EtBr prepared in $20 \mathrm{~m} M \mathrm{MB}, \mathrm{pH} 10.0$. Capillary: $60 \mathrm{~cm}$ total length and $50 \mathrm{~cm}$ effective length, filled with $40 \mathrm{~m} M \mathrm{DB}$ buffer, $\mathrm{pH}$ 12.0. Electrokinetic injection was conducted at $16.7 \mathrm{~V} / \mathrm{cm}$ for $10 \mathrm{~s}$. 
HEC, but not $1.7 \%$ HEC. Because the concentration of HEC used was much higher than its entanglement threshold $(0.37 \%)$ [20], we suggest that sieving of DNA by HEC solutions takes place.

\subsection{Separation of the $5 \mathrm{~kb} D N A$ ladder}

Next we tested the separation of the $5 \mathrm{~kb}$ DNA ladder (the longest DNA fragment is $40 \mathrm{kbp}$ ) in the presence of EOF using 1.5\% HEC prepared in $20 \mathrm{~m} M$ MB buffer at different $\mathrm{pH}$ values and the capillary filled with $40 \mathrm{~m} M$ DB buffer, $\mathrm{pH}$ 8.0-12.0. The separations were unsuccessful when using $1.5 \%$ HEC at $\mathrm{pH}<11.0$ (not shown), mainly because of the high EOF (shorter separation time), thereby causing poor resolution. When using $1.5 \%$ HEC at

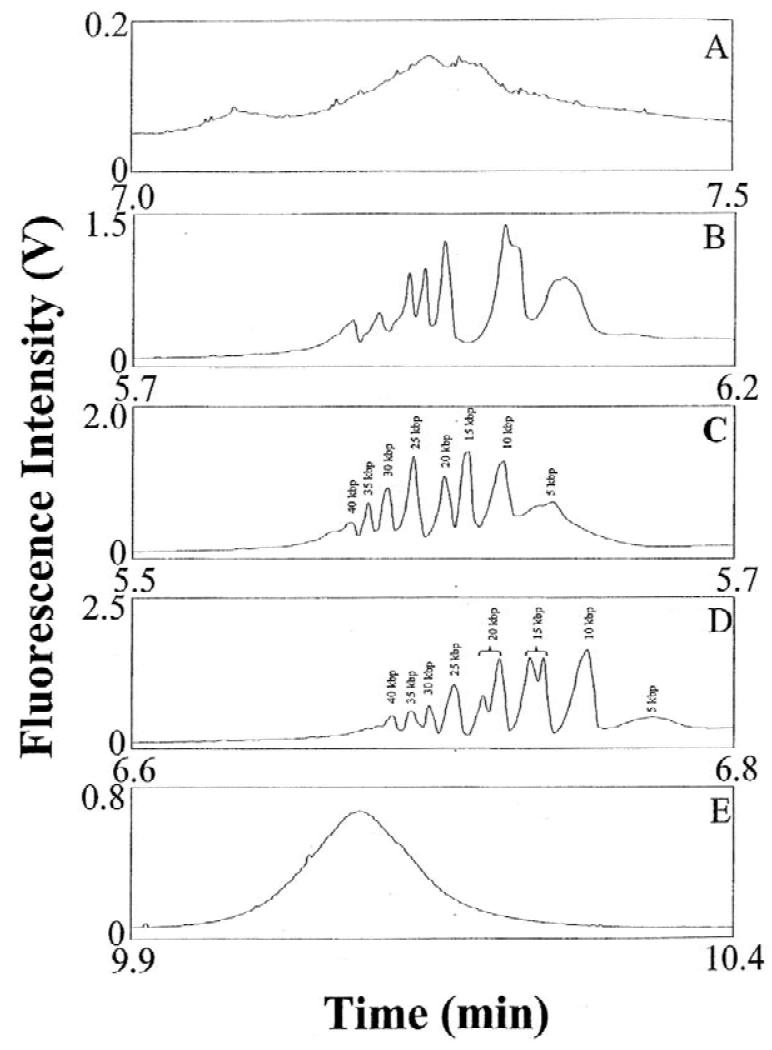

Fig. 2. Separation of the $5 \mu \mathrm{g} / \mathrm{mL} 5 \mathrm{~kb}$ DNA ladder in the presence of EOF at $125 \mathrm{~V} / \mathrm{cm}$ using $1.5 \%$ HEC solutions containing $5 \mu \mathrm{g} / \mathrm{mL}$ EtBr prepared in $20 \mathrm{~m} M \mathrm{MB}, \mathrm{pH} 12.0$. Capillary: $40 \mathrm{~cm}$ total length and $30 \mathrm{~cm}$ effective length, filled with $40 \mathrm{~m} M$ DB buffer at (A) pH 8.0, (B) 9.0, (C) 10.0, (D) 11.0, and (E) 12.0. Other conditions as in Fig. 1.
$\mathrm{pH} 12.0$ and the capillary filled with $40 \mathrm{~m} M$ DB buffer, $\mathrm{pH} 8.0$ or 9.0 , the separations also failed, as shown in Fig. 2A and B. This is probably due to Joule heating because of partial protonation of the amine and the existence of relatively large amounts of boric acid in the system. For example, 0.78, 0.44, $0.20,0.10$ and $0.01 \mathrm{~g}$ boric acid were added to prepare $40 \mathrm{~m} M$ DB buffers, $\mathrm{pH}$ 8.0, 9.0, 10.0, 11.0 and 12.0, respectively. Fig. $2 \mathrm{C}$ shows that eight peaks were resolved in 6 min using a capillary filled with $40 \mathrm{~m} M$ DB, $\mathrm{pH}$ 10.0. The electropherogram in Fig. 2D shows that 10 peaks were resolved when the capillary was filled with $40 \mathrm{~m} M \mathrm{DB}, \mathrm{pH} 11.0$, indicating that the sample contained more than the eight DNA fragments suggested by the manufacture. This indicates that our proposed method provides either high resolving power or greater sensitivity at high $\mathrm{pH}$. The success of the separation might also be due to changes in DNA conformation (e.g. from $J$ to I shape), presumably because of the existence of the EOF and the high viscosity of HEC matrices with small pore sizes [37]. Changes in DNA conformation due to a fast flow-rate and viscosity have also been investigated and tested for the separation of large DNA fragments ( $>5 \mathrm{kbp}$ ) in slalom chromatography $[38,39]$. We point out that the separations were unsuccessful under isocratic conditions using the same buffers to prepare HEC solutions and to fill the capillary at $\mathrm{pH} 8.2-12.0$, indicating that $\mathrm{pH}$ changes play an important role in improving the resolution. This might be due to conformation changes when DNA migrates in environments of different $\mathrm{pH}$ and background electrolytes.

For comparison, we performed separations of the same DNA sample in the absence of EOF using a PVP-coated capillary and $0.05 \%$ HEC at $\mathrm{pH} 10.0$, 11.0, and 12.0, separately. Fig. 3A shows that the separation was only successful at $\mathrm{pH} 10.0$, which is similar to that at $\mathrm{pH} 8.2$ and 9.0 (not shown). Unlike separation in the presence of an EOF, DNA was only separated at extremely low concentrations (e.g. $0.05 \%)$ of HEC, far below its $\Phi^{*}$ [20]. Note that the migration order is reversed compared with that in Fig. 2. It should be pointed out that the loss of resolution between the $35 / 40 \mathrm{kbp}$ DNA pairs occurred at $\mathrm{pH} 11.0$ and 12.0, as shown in Fig. 3B and $\mathrm{C}$. These results suggest that the separation of large DNA fragments based on the mechanism in 


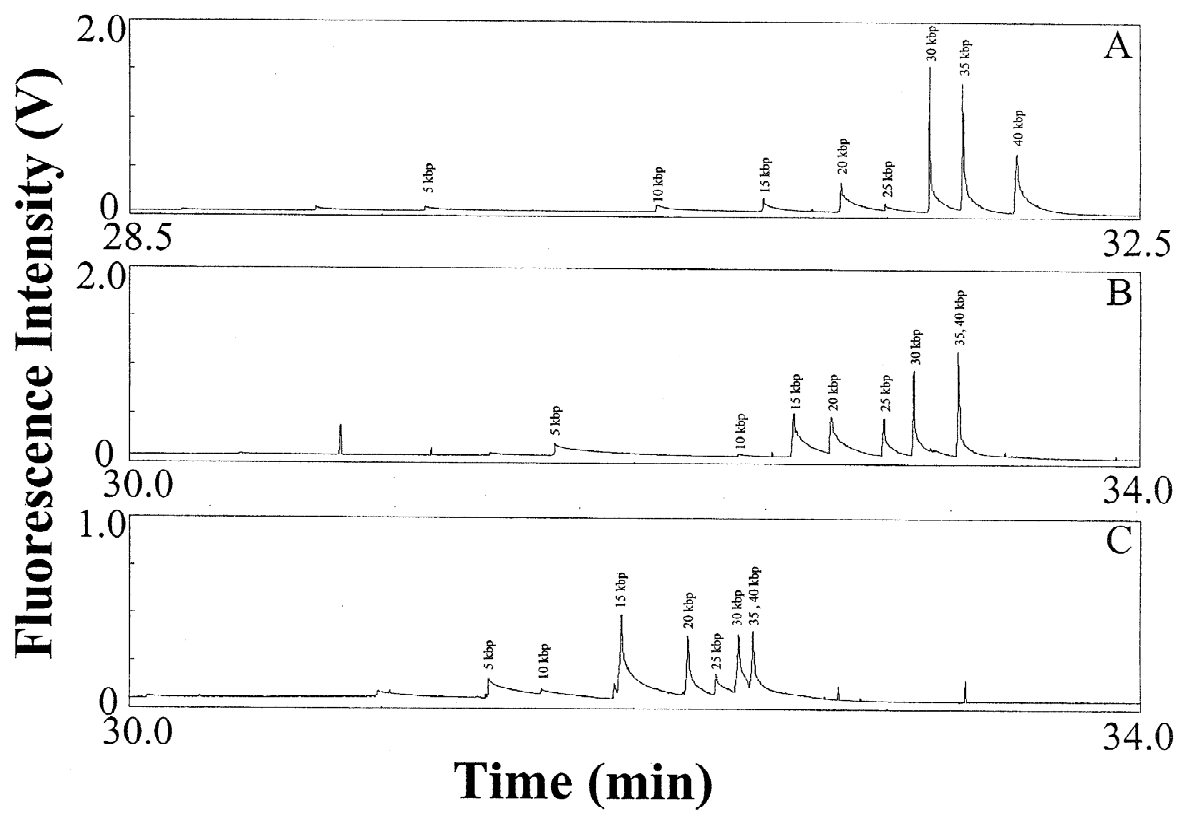

Fig. 3. Separation of a $25 \mu \mathrm{g} / \mathrm{mL} 5 \mathrm{~kb}$ DNA ladder in the absence of EOF at $-25 \mathrm{~V} / \mathrm{cm}$ using $0.05 \%$ HEC solutions prepared in $20 \mathrm{~m} M$ $\mathrm{MB}$ at (A) $\mathrm{pH} 10.0$, (B) 11.0 and (C) 12.0, containing $5 \mu \mathrm{g} / \mathrm{mL}$ EtBr. Capillary: $40 \mathrm{~cm}$ total length and $30 \mathrm{~cm}$ effective length, filled with $40 \mathrm{~m} M$ DB buffers, $\mathrm{pH}$ 10.0, 11.0, and 12.0, respectively. Other conditions as in Fig. 1.

which DNA drags along the polymer molecules is problematic at high $\mathrm{pH}$. The loss of resolution at $\mathrm{pH}$ 12.0 was also partially due to denaturation of DNA. In comparison, we conclude that separations in the presence of an EOF using higher concentrations of HEC solutions are faster. To this end, we suggest that low concentrations of HEC are appropriate in the absence of an EOF, while higher concentrations of HEC are superior for the separation of large DNA fragments at high $\mathrm{pH}$.

To minimize the electric dispersion of DNA, which is proportional to the contour length of DNA [40], the separation of large DNA fragments has commonly been conducted at low electric field strengths (several tens $\mathrm{V} / \mathrm{cm}$ ). To further investigate the impact of the electric field strength, we separately conducted separations at 75, 125, 250, and 375 $\mathrm{V} / \mathrm{cm}$. At $75 \mathrm{~V} / \mathrm{cm}$, all peaks co-migrated at a time of $10.9 \mathrm{~min}$. DNA fragments less than $25 \mathrm{kbp}$ were resolved in a shorter period of time, while DNA fragments greater than $30 \mathrm{kbp}$ co-migrated at 250 or $375 \mathrm{~V} / \mathrm{cm}$. For example, the resolution values for $5 / 10,20 / 25$, and $35 / 40 \mathrm{kbp}$ were $1.5,1.7$, and 0.4 at $125 \mathrm{~V} / \mathrm{cm}, 4.9,1.8$, and 0 at $250 \mathrm{~V} / \mathrm{cm}$, and $7.7,1.9$, and 0 at $375 \mathrm{~V} / \mathrm{cm}$, respectively. As the electric field increases, dispersion proportional to the DNA size is predicted and thermal effects may dominate over diffusion [41]. In addition, shorter differential migration times contribute to the loss of resolution at high electric field strengths. Overall, the optimum electric field strength is $125 \mathrm{~V} / \mathrm{cm}$, as shown in Fig. 2D. The results also suggest that voltage gradient techniques are promising for optimum resolution when separating DNA fragments with a wide range of sizes.

\section{Conclusions}

The effects of $\mathrm{pH}$ and background electrolyte prepared from three different amines on the separation of DNA in the presence of an EOF have been investigated. Separations of large DNA fragments at $\mathrm{pH}>10.0$ have been demonstrated, with improvements in sensitivity (about five- to eight-fold). Unlike for separation using $1 \times$ TBE buffer, the use of HEC solution with concentrations much greater than its entanglement threshold is essential for optimum resolution in the separation of large DNA fragments 
in the presence of an EOF at high $\mathrm{pH}$. The resolution increases with increasing HEC concentration at high $\mathrm{pH}$, mainly because of the decrease in diffusion and the change in DNA conformation. In addition, DNA migrating against the EOF should be one of the most important contributors for better resolution. Compared with separation in the absence of an EOF, this method allows faster separation. Unlike when using pressure, the difficulty of filling the capillary with viscous polymer solutions no longer exists. One other advantage of using this approach for the analysis of large DNA fragments is the possibility of separating large volumes of DNA samples using a viscous polymer solution [42-44]. Thus our future experimental aims will focus on applying this method to the recovery of large-sized DNA such as important genes from biological samples.

\section{Acknowledgements}

This work was supported by the National Science Council of Taiwan under contract number NSC 902113-M002-058.

\section{References}

[1] H. Zhou, A.W. Miller, Z. Sosic, B. Buchholz, A.E. Barron, L. Kotler, B.L. Karger, Anal. Chem. 72 (2000) 1045.

[2] J. Zhang, M. Yang, X. Puyang, Y. Fang, L.M. Cook, N.J. Dovichi, Anal. Chem. 73 (2001) 1234.

[3] H. Tan, E.S. Yeung, Anal. Chem. 70 (1998) 4044.

[4] T.K. Christopoulos, Anal. Chem. 71 (1999) 425R.

[5] Y. Baba, J. Chromatogr. B 687 (1996) 271.

[6] O. Salas-Solano, E. Carrilho, L. Kotler, A.W. Miller, W. Goetzinger, Z. Sosic, B.L. Karger, Anal. Chem. 70 (1998) 3996.

[7] K. Klepárník, Z. Malá, P. Boček, Electrophoresis 22 (2001) 783.

[8] M. Chiari, S. Riva, A. Gelain, A. Vitale, E. Turati, J. Chromatogr. A 781 (1997) 347.

[9] C. Heller, Electrophoresis 20 (1999) 1962.

[10] R.W. Hammond, H. Oana, J.J. Schwinefus, J. Bonadio, R.J. Levy, M.D. Morris, Anal. Chem. 69 (1997) 1192.

[11] D.H. Atha, Electrophoresis 19 (1998) 1428.

[12] G. Raucci, C.A. Maggi, D. Parente, Anal. Chem. 72 (2000) 821.
[13] Q. Gao, E.S. Yeung, Anal. Chem. 20 (1998) 1382.

[14] H.-T. Chang, E.S. Yeung, J. Chromatogr. B 669 (1995) 113.

[15] J. Horvath, V. Dolník, Electrophoresis 22 (2001) 644.

[16] P.G. Righetti, C. Gelfi, B. Verzola, L. Castelletti, Electrophoresis 22 (2001) 603.

[17] R.K. Moyzis, J.M. Buckingham, L.S. Cram, M. Dani, L.L. Deaven, M.D. Jones, J. Meyne, R.L. Ratliff, J.-R. Wu, Proc. Natl. Acad. Sci. USA 85 (1988) 6622.

[18] L. Mitnik, L. Salomé, J.L. Viovy, C. Heller, J. Chromatogr. A 710 (1995) 309.

[19] Y. Kim, M.D. Morris, Anal. Chem. 67 (1995) 784.

[20] A.E. Barron, W.M. Sunada, H.W. Blanch, Electrophoresis 17 (1996) 744.

[21] A.E. Barron, H.W. Blanch, D.S. Soane, Electrophoresis 15 (1994) 597.

[22] X. Shi, R.W. Hammond, M.D. Morris, Anal. Chem. 67 (1995) 1132.

[23] A.E. Barron, W.M. Sunada, H.W. Blanch, Electrophoresis 16 (1995) 64.

[24] H.-S. Chen, H.-T. Chang, Electrophoresis 19 (1998) 3149.

[25] H.-S. Chen, H.-T. Chang, Anal. Chem. 71 (1999) 2033.

[26] W.-L. Tseng, M.-M. Hsieh, S.-J. Wang, H.-T. Chang, J. Chromatogr. A 894 (2000) 219.

[27] J. Ren, P.M. Ueland, Hum. Mutat. 13 (1999) 458.

[28] T. Nock, J. Dove, B. McCord, D. Mao, Electrophoresis 22 (2001) 755.

[29] S. Magnusdottir, C. Gelfi, M. Hamdan, P.G. Righetti, J. Chromatogr. A 859 (1999) 87.

[30] Z. Malá, K. Klepárník, P. Boček, J. Chromatogr. A 853 (1999) 371.

[31] Y. Liu, W.G. Kuhr, Anal. Chem. 71 (1999) 1668.

[32] W.-L. Tseng, H.-T. Chang, Electrophoresis 22 (2001) 763.

[33] J.-B. LePecq, C. Paoletti, J. Mol. Biol. 27 (1967) 87.

[34] P.H. Johnson, L.I. Grossman, Biochemistry 16 (1977) 4217.

[35] N.C. Stellwagen, A. Bossi, C. Gelfi, P.G. Righetti, Anal. Biochem. 287 (2000) 167.

[36] S.M. Clark, R.A. Mathies, Anal. Chem. 69 (1997) 1355.

[37] M. Ueda, H. Oana, Y. Baba, M. Doi, K. Yoshikawa, Biophys. Chem. 71 (1998) 113.

[38] E. Peyrin, Y.C. Guilaume, A. Villet, A. Favier, Anal. Chem. 72 (2000) 853.

[39] J. Hirabayashi, K. Kasai, J. Chromatogr. A 893 (2000) 115.

[40] Š. Popelka, Z. Kabátek, J.-L. Viovy, B. Gaš, J. Chromatogr. A 838 (1999) 45.

[41] C. Heller, Electrophoresis 22 (2001) 629.

[42] M.-M. Hsieh, W.-L. Tseng, H.-T. Chang, Electrophoresis 21 (2000) 2904

[43] W.-L. Tseng, M.-M. Hsieh, S.-J. Wang, C.-C. Huang, Y.-C. Lin, P.-L. Chang, H.-T. Chang, J. Chromatogr. A 927 (2001) 179.

[44] C.-C. Huang, M.-M. Hsieh, T.-C. Chiu, H.-T. Chang, Electrophoresis 22 (2001) 4328. 